\title{
Beneficial Biological Activities of Cinnamomum osmophloeum and Its Potential Use in the Alleviation of Oral Mucositis: A Systematic Review
}

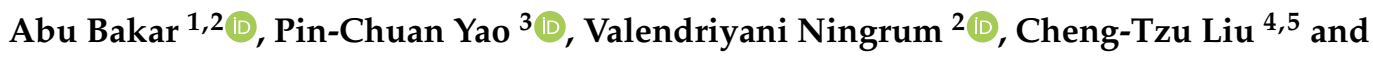 \\ Shih-Chieh Lee ${ }^{6, *(\mathbb{D})}$ \\ 1 PhD Program of Biotechnology and Industry, Da-Yeh University, Dacun, Changhua 51591, Taiwan; \\ abuba.mmed@gmail.com \\ 2 School of Dentistry, Baiturrahmah University, Kuranji, Padang 25155, Indonesia; valend888@gmail.com \\ 3 Department of Material Science and Engineering, Da-Yeh University, Dacun, Changhua 51591, Taiwan; \\ pcyao@mail.dyu.edu.tw \\ 4 School of Nutrition, Chung Shan Medical University, Taichung 40201, Taiwan; ctl@csmu.edu.tw \\ 5 Department of Nutrition, Chung Shan Medical University Hospital, Taichung 40201, Taiwan \\ 6 Department of Food Science and Biotechnology, Da-Yeh University, Dacun, Changhua 51591, Taiwan \\ * Correspondence: slee@mail.dyu.edu.tw
}

Received: 19 November 2019; Accepted: 30 December 2019; Published: 1 January 2020

\begin{abstract}
The aim of this review was to provide an updated overview of studies on the medical-biological activities of Cinnamomum osmophloeum (C. osmophloeum) in vitro and in vivo and the potential therapeutic use of natural agents prepared from this plant for the alleviation of oral mucositis (OM). Reported articles were collected using web search engine tools. The systematic review was organized according to the preferred reporting items for reviews and meta-analyses (PRISMA) statement. Additional sources were identified through cross-referencing to identify the potential use of $C$. osmophloeum in the alleviation of OM. The results disclosed that C. osmophloeum is comprised of bioactive ingredients that could act diversely as a reagent in anti-inflammation, antibacterial, antioxidant, anti-hyperglycemic, antidyslipidemia, anti-cancer, renal disease therapy and anti-hyperuricemia capacities. Recent studies revealed that the overall effects on anti-inflammation, wound repair, and the antibacterial and antioxidant activities of its constituents would act as a potential remedy for oral mucositis. Up-to-date in vitro and in vivo studies on the medical-biological activities of C. osmophloeum suggested that C. osmophloeum and its constituents could be promising remedies as adjuvants in OM therapy and warrant further investigation.
\end{abstract}

Keywords: C. osmophloeum; biological activities; oral mucositis; cinnamaldehyde; linalool

\section{Introduction}

Cinnamon plants (Cinnamomum spp.) are of the genus Lauraceae, native to South and Southeast Asia, and are generally used as food flavors and traditional medicinal plants. Cinnamomum osmophloeum, commonly known as indigenous cinnamon or pseudocinnamon, is endemic to Taiwan's natural hardwood forests [1]. Major components of the essential oils extracted from C. osmophloeum leaves explored by high-performance liquid chromatography (HPLC) are as follows: $\alpha$-pinene, camphene, benzaldehyde, $\beta$-pinene, 3-pheayl pionaldehyde, cis-cinnamaldehyde, trans-cinnamaldehyde, isobornylacetate, eugenol, and cinnamil acetate [2]. The essential oils extracted from C. osmophloeum leaves comprise 101 volatile compounds, as identified by GC/MS analysis, including monoterpenoids, sesquiterpenoids, alcohols, phenols, aldehydes, ketones, esters, acids, and other miscellaneous compounds. It was demonstrated that the linalool chemotypes present 
in C. osmophloeum were as follows: linalool, trans-cinnamyl acetate, camphor, cinnamaldehyde, 3-phenyl-2-propenal, caryophyllene, coumarin, bornyl acetate, limonene, $\alpha-(+)$-pinene, estragole, and caryophyllene oxide [3]. In several studies (both in vitro and in vivo), C. osmophloeum has been applied as an alternative natural therapy to treat certain compromised and uncompromised diseases [3-7].

Oral mucositis (OM) is known as the inflammation of oral mucosa, usually occurring as an adverse side-effect of chemotherapy and/or radiation therapy (radiotherapy), and is manifested as atrophy, swelling, erythema, and ulceration [8]. OM occurrence in the hospital might increase costs and deteriorate oral health quality of life [9-11]. Hence, oral care treatments, including nutritional care, pain control, oral cleansing, palliation of a dry mouth, bleeding handling, and medicinal interventions have been introduced to decrease the severity of OM after cancer therapy [12]. Patients receiving radiotherapy to head and neck areas are at a significant risk of developing oral mucositis. The risk is lower (less than $50 \%$ or little risk) in patients with prolonged chemotherapy, patients receiving surgery, and patients with radiotherapy to non-head and neck areas $[10,13]$. The underlying pathophysiology of $\mathrm{OM}$ is divided into five phases: (1) initiation, (2) primary damage response, (3) signaling and amplification, (4) ulceration (symptomatic phase), and (5) healing [14-16]. The first phase (initiation stage) happens after exposure to radiotherapy or chemotherapy. It consists of two events: DNA breakdown and the generation of reactive oxygen species (ROS). DNA strand breakdowns lead to direct injury and death of the cells, and reactive oxygen species play a role as key initiators and mediators of downstream biological events. During the second phase (primary damage response), activator transduction pathways are stimulated by the DNA breaks strand, which can lead to the activation of several transcription factors, including p53 and nuclear factor kappa-B (NF- $\mathrm{B}$ ). NF- $\mathrm{k}$ B works as a controller for the expression of a broad range of genes, and produces a series of mediators, including pro-inflammatory cytokines and both pro- and anti-apoptotic cellular changes. During phase III (signal amplification stage), pro-inflammatory cytokines deliver a positive reaction to enhance and accelerate the process of wound healing. During phase IV (ulceration phase, also called symptomatic phase), it is common for the mucosal surface to become re-infected with bacteria. Bacterial invasion stimulates macrophage accumulation to conceal additional amounts of pro-inflammatory cytokines. During phase $\mathrm{V}$ (healing stage), signals from the connective tissue to the bordering epithelium can activate the migration, propagation, and differentiation of cells, resulting in healed mucosa. A number of biomaterials explored for OM therapy perform their principal mechanisms linked to pathophysiology by depressing pro-inflammatory cytokines. In addition to anti-inflammation, antioxidant, antifungal, antibacterial, and immunomodulator mechanisms of action have been reported [17]. As one of the encouraging biomaterials, C. osmophloeum might be a potential alleviator of OM.

Previous studies on cinnamon have been limited to C. osmophloeum [1]. However, different species of cinnamon might possess diverse beneficial biological activities aiming at various medical therapies. Therefore, we have provided an updated extensive overview on studies of the medical-biological activities of C. osmophloeum and its principal ingredients, both in vitro and in vivo. The potential use of this natural component in oral mucositis therapy is also discussed.

\section{Materials and Methods}

A computerized search for the reported works was performed through PubMed ${ }^{\circledR}$, Scopus, ScienceDirect, and Web of Science databases by using the key words "cinnamon osmophloeum", "indigenous cinnamon", and "pseudocinnamon". A systematic review was conducted following PRISMA. In order to identify the potential use of C. osmophloeum in the alleviation of OM, additional sources were identified through cross-referencing.

In addition, previously published review articles were searched to gain additional information. In order to identify the potential use of C. osmophloeum in the alleviation of OM induced by radiotherapy and/or chemotherapy, a second computerized search using PubMed ${ }^{\circledR}$, Scopus, ScienceDirect, and Web of Science databases was carried out by utilizing keywords with C. osmophloeum constituents that possess anti-inflammation, antioxidant, and antibacterial activities with OM, including "cinnamaldehyde 
+ oral mucositis", "trans-cinnamaldehyde + oral mucositis", "kaempferitin + oral mucositis", "kaempferol + oral mucositis", "cinnamic acid + oral mucositis", "cinnamyl alcohol + oral mucositis", "cinnamyl acetate + oral mucositis", "alloaromadendrene + oral mucositis", and "linalool + oral mucositis".

\section{Results and Discussion}

\subsection{Medical-Biological Activities of C. osmophloeum}

A set of 51 articles related to C. osmophloeum was identified, in which 18 articles were excluded because they were duplicate papers $(n=2)$, were not related to the beneficial biological activities $(n$ $=2$ ), or were irrelevant articles $(n=14)$. Irrelevant articles involved studies not related to medical uses, studies related to mushroom planting in C. osmophloeum, and review article(s) (Figure 1). Specific studies (2 to 4 ) discussed the beneficial biological activities [3,18-22] and suggested more than one chemical compound as the active content. Some beneficial biological activities have been summarized in Table 1 and consist of anti-inflammatory activities [20,22-30], wound repair activities [20], antibacterial activities [31,32], antifungal activities [33,34], antioxidant activities [18,20,35-37], anti-hyperglycemic activities [3,18,21], antidyslipidemia activities [38,39], anti-cancer and anti-tumor activities [22], renal disease therapy, and anti-hyperuricemia activities [2,4]. In addition, studies on the leaves, twigs, barks, heartwoods, and roots of C. osmophloeum were also reported.

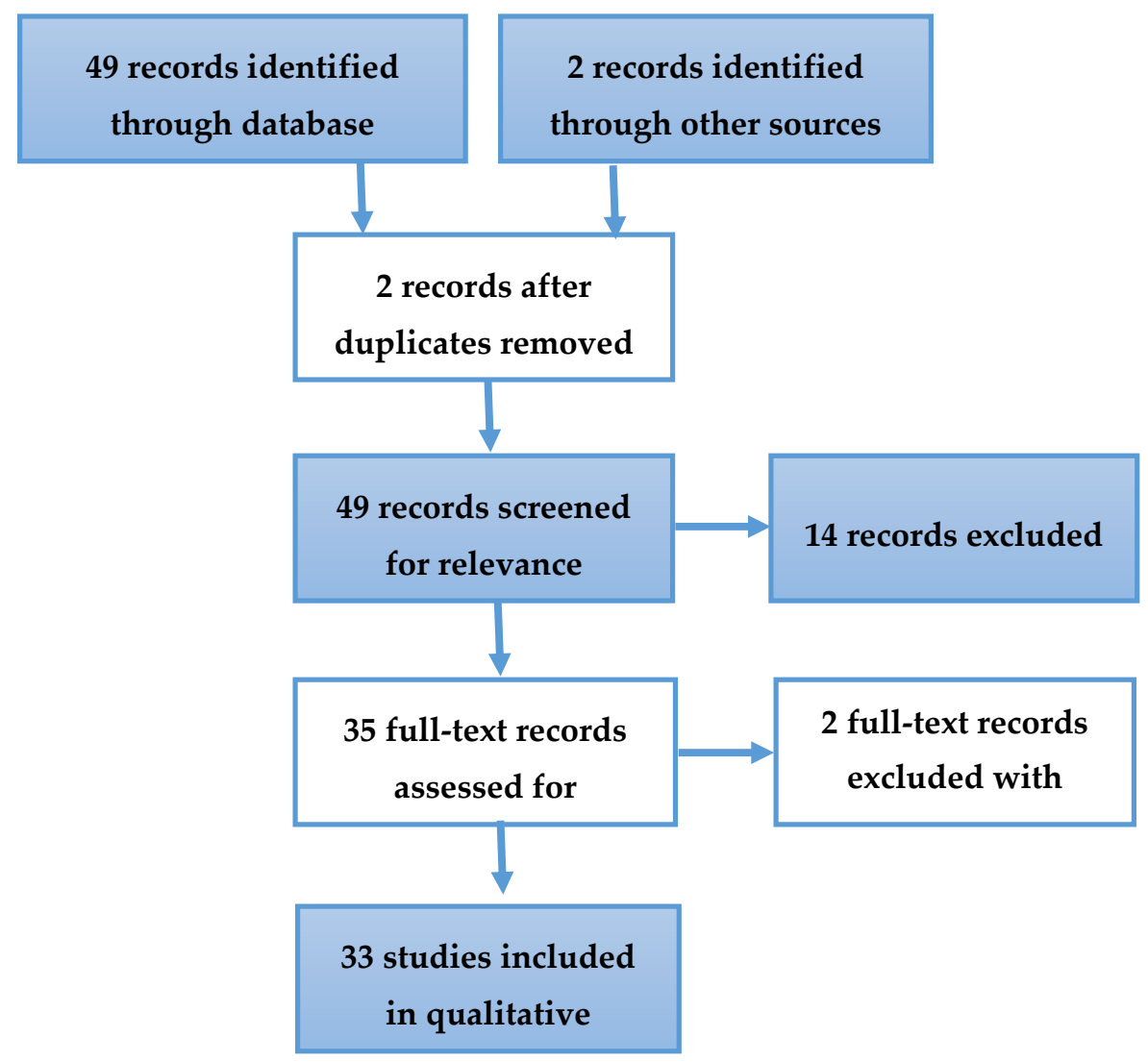

Figure 1. The systematic search for medical-biological activities of Cinnamomum osmophloeum. 
Table 1. Beneficial biological activities of C. osmophloeum.

\begin{tabular}{|c|c|c|c|c|c|c|}
\hline Bioactivity & Chemical Identification & C. osmophloeum Parts & Constituent (s) & Study & Mechanisms & Reference \\
\hline \multirow{8}{*}{$\begin{array}{l}\text { Anti-inflammatory } \\
\text { effect }\end{array}$} & LC-MS/MS & Leaves & Kaempferitrin & In vitro & $\begin{array}{l}\text { Down-regulate the extracellular LDL-R } \\
\text { (chronic inflammation-related diabetes } \\
\text { mellitus) }\end{array}$ & Ku et al., (2017) [26] \\
\hline & GC-MS & Twigs & $\begin{array}{l}\text { Trans-cinnamaldehyde, } \\
\text { caryophyllene oxide, } \\
\text { L-borneol, L-bornyl acetate, } \\
\text { eugenol, } \beta \text {-caryophyllene, } \\
\text { E-nerolidol, and cinnamyl }\end{array}$ & In vitro & $\begin{array}{l}\text { Suppressing nitric oxide synthesis by } \\
\text { LPS-stimulated macrophages }\end{array}$ & Tung et al. (2008) [30] \\
\hline & GC-MS & Leaves & $\begin{array}{l}\text { Trans-cinnamaldehyde,(-) } \\
\text {-aromadendrene, } \\
\text { caryophyllene oxide, } \\
\text { T-cadinol, and } \alpha \text {-cadinol }\end{array}$ & In vitro & $\begin{array}{l}\text { Suppressing nitric oxide production by } \\
\text { LPS-stimulated macrophages }\end{array}$ & Tung et al. (2010) [29] \\
\hline & GC-MS and HPLC & Leaves & Cinnamaldehyde & In vitro & $\begin{array}{l}\text { Cinnamaldehyde inhibits LPS-mediated } \\
\text { pro-inflammatory cytokine production }\end{array}$ & Chao et al. (2008) [23] \\
\hline & TLC & Leaves & NA & In vitro & $\begin{array}{l}\text { Inhibition of the production of } \mathrm{NO} \text { and } \\
\text { cytokines (TNF-a and IL-12), from } \\
\text { LPS/IFNc-activated macrophages }\end{array}$ & $\begin{array}{l}\text { Fang, Rao \& Tzeng (2005) } \\
\text { [25] }\end{array}$ \\
\hline & $\begin{array}{l}\text { CC, HPLC, TLC, ESIMS, } \\
\text { and GC-MS }\end{array}$ & Twigs & Kaempferol glycosides & In vitro & Nitric oxide production inhibitory activities & Lin \& Chang(2012) [28] \\
\hline & GC-MS & Leaves & $\begin{array}{l}\text { Linalool and } \\
\text { cinnamaldehyde }\end{array}$ & In vivo & $\begin{array}{l}\text { Inhibition of the expression of molecules in } \\
\text { both TLR4 and NLRP3 signaling pathways }\end{array}$ & Lee et al. (2018) [40] \\
\hline & GC-MS & Leaves & $\begin{array}{l}21 \text { compounds were } \\
\text { identified }\end{array}$ & In vitro & Inhibition of IL-1â and IL-6 production & Chao et al. (2005) [24] \\
\hline \multirow[b]{2}{*}{ Antibacterial activity } & GC & Leaves & Cinnamaldehyde & In vitro & Bactericidal & $\begin{array}{l}\text { Chang, Chen \& Chang } \\
\text { (2001) [32] }\end{array}$ \\
\hline & GC-MS & Leaves & $\begin{array}{l}\text { Cinnamaldehyde, cinnamic } \\
\text { acid, cinnamyl alcohol, and } \\
\text { cinnamyl acetate }\end{array}$ & In vitro & Bacterial inhibition & Chang et al. (2008) [31] \\
\hline \multirow{2}{*}{ Antifungal activity } & GC-MS & Leaves & Cinnamaldehyde & In vitro & NA & Cheng et al. (2006) [34] \\
\hline & GC-MS & Leaves & Cinnamaldehyde & In vitro & NA & $\begin{array}{l}\text { Wang, Chen \& Chang } \\
\text { (2005) [33] }\end{array}$ \\
\hline \multirow[t]{4}{*}{ Antioxidant activities } & ESIMS & Twigs & Kaempferol-7-O-rhamnoside & In vitro & NA & $\begin{array}{l}\text { Chua, Tung, \& Chang } \\
\text { (2008) [35] }\end{array}$ \\
\hline & $\begin{array}{l}\text { GC-MS and } \\
\text { GC-FID }\end{array}$ & Leaves & Alloaromadendrene & In vitro & NA & Yu et al. (2014) [41] \\
\hline & GC-MS and GC-FID & Leaves & Trans-cinnamaldehyde & In vitro & NA & Yeh et al. (2013) [37] \\
\hline & GC-MS and GC-FID & Leaves & Trans cinnamaldehyde & In vivo & $\begin{array}{l}\text { Expression of antioxidative-related genes } \\
\text { was pointedly affected by essential oils from } \\
\text { C. osmophloeum. }\end{array}$ & Hsu et al. (2012) [36] \\
\hline
\end{tabular}


Table 1. Cont

\begin{tabular}{|c|c|c|c|c|c|c|}
\hline Bioactivity & Chemical Identification & C. osmophloeum Parts & Constituent (s) & Study & Mechanisms & Reference \\
\hline $\begin{array}{l}\text { Antidyslipidemic } \\
\text { activity }\end{array}$ & HPLC & Leaves & $\begin{array}{l}\text { Kaempferol and } \\
\text { kaempferitrin }\end{array}$ & In vivo & Cholesterol-lowering activity & Lin et al. (2011) [38] \\
\hline $\begin{array}{l}\text { Anti-hyperglycemic } \\
\text { and antioxidant } \\
\text { activities }\end{array}$ & $\begin{array}{c}\text { A modified } \\
\text { vanillin- } \mathrm{H}_{2} \mathrm{SO}_{4} \text { assay } \\
\text { A modified acid-butanol } \\
\text { assay } \\
\text { The } \mathrm{AlCl}_{3} \text { method }\end{array}$ & Twigs & $\begin{array}{l}\text { Proanthocyanidin and } \\
\text { tannin contents }\end{array}$ & In vitro & $\begin{array}{l}\text { CoTE has PTP1B inhibitory activity to } \\
\text { improve insulin or leptin resistance }\end{array}$ & Lin et al. (2016) [18] \\
\hline $\begin{array}{l}\text { Hepatoprotective } \\
\text { effects }\end{array}$ & NA & Leaves & $\begin{array}{l}\text { trans-cinnamaldehyde, } \\
\text { ()-aromadendrene, } \\
\text { T-cadinol, or R-cadinol }\end{array}$ & In vivo & $\begin{array}{l}\text { The modulation of anti-inflammatory } \\
\text { activities (decreased the aspartate } \\
\text { aminotransferase (AST), alanine } \\
\text { aminotransferase (ALT), tumor necrosis } \\
\text { factor-R (TNF-R), and interleukin 6 (IL-6) } \\
\text { levels in serum) }\end{array}$ & Tung et al. (2011) [6] \\
\hline $\begin{array}{l}\text { Pancreas Protective } \\
\text { Effect and } \\
\text { Hypoglycemic } \\
\text { activity }\end{array}$ & GC/MS & Leaves & Linalool & In vivo & $\begin{array}{l}\text { 1. Decreased pancreatic values of } \\
\text { thiobarbituric acid reactive substances and } \\
\text { activities of superoxide dismutase and } \\
\text { glutathione reductase } \\
\text { 2. Decreased pancreatic levels of } \\
\text { interleukin-1 } \beta \text { and nitric oxide }\end{array}$ & Lee et al. (2013) [3] \\
\hline $\begin{array}{l}\text { Prevent Cardiac } \\
\text { Hypertrophy }\end{array}$ & HPLC & Leaves & Cinnamaldehyde & In vivo & $\begin{array}{l}\text { The protective role of cinnamaldehyde } \\
\text { related to the ERK } 1 / 2 \text { signaling pathway. }\end{array}$ & Yang et al. (2015) [7] \\
\hline $\begin{array}{l}\text { Treatment of renal } \\
\text { interstitial fibroblasts }\end{array}$ & NA & Leaves & Cinnamaldehyde & In vitro & $\begin{array}{l}\text { Inhibit high glucose-induced hypertrophy } \\
\text { (decreased cell size; cellular hypertrophy } \\
\text { index; and protein levels of collagen IV, } \\
\text { fibronectin, and } \alpha \text {-smooth muscle actin). }\end{array}$ & Chao et al. (2010) [4] \\
\hline $\begin{array}{l}\text { Anticancer (liver and } \\
\text { oral cancer) }\end{array}$ & TLC, CC and HPLC & Heart wood and roots & Lignan Esters & In vitro & Tumor cell growth inhibition & Chen et al. (2010) [42] \\
\hline Anti-diabetes & TLC & Twigs & $\begin{array}{l}\text { Kaempferol glycosides } \\
\text { CO-1 and CO-2 }\end{array}$ & In vitro & $\begin{array}{l}\text { Enhanced adiponectin secretion, and } \\
\text { activation of the insulin signaling pathway }\end{array}$ & Lee et al. (2009) [43] \\
\hline $\begin{array}{l}\text { Anti-hyperuricemia } \\
\text { effect }\end{array}$ & GC-MS & Leaves & Cinnamaldehyde & In vivo & $\begin{array}{l}\text { Acts as a xanthine oxidase inhibitor and } \\
\text { reduces the serum uric acid levels }\end{array}$ & Wang et al. (2008) [2] \\
\hline Anxiolytic properties & HPLC & Leaves & Linalool & In vivo & $\begin{array}{l}\text { Reduced the amount of 5-HT, DA and NE } \\
\text { and increased the level of dopamine in } \\
\text { striatum }\end{array}$ & Cheng et al. (2014) [44] \\
\hline $\begin{array}{l}\text { Wound Repair } \\
\text { Promoter and } \\
\text { Antioxidant }\end{array}$ & NA & Leaves & NA & In vitro and in vivo & $\begin{array}{l}\text { Inhibited tyrosinase activity and reduced } \\
\text { melanin content }\end{array}$ & Lee et al. (2015) [20] \\
\hline $\begin{array}{l}\text { Anti-inflammatory } \\
\text { and anti-cancer } \\
\text { properties }\end{array}$ & NA & Barks & NA & In vivo & $\begin{array}{l}\text { The growth inhibition of NO, TNF-, and } \\
\text { IL-12, and tumor cell proliferation }\end{array}$ & Rao et al. (2007) [22] \\
\hline Hypolipidemic effects & NA & Leaves & S-(p)-linalool & In vivo & $\begin{array}{l}\text { Inhibited lipid accumulation through } \\
\text { downregulation of 3T3-L1 adipocyte } \\
\text { differentiation }\end{array}$ & Cheng et al. (2018) [39] \\
\hline
\end{tabular}


Table 1. Cont.

\begin{tabular}{|c|c|c|c|c|c|c|}
\hline Bioactivity & Chemical Identification & C. osmophloeum Parts & Constituent (s) & Study & Mechanisms & Reference \\
\hline $\begin{array}{l}\text { Effect on the human } \\
\text { immune system }\end{array}$ & HS-GC/MS and HPLC & Leaves & Cinnamaldehyde & In vivo & Cytokines modulatory effect & Lin et al. (2011) [45] \\
\hline $\begin{array}{c}\text { Potential } \\
\text { skin-whitening and } \\
\text { protective agent }\end{array}$ & NA & Leaves & $\begin{array}{l}\text { Cinnamaldehyde and } \\
\text { cinnamylacetate }\end{array}$ & In vitro & $\begin{array}{l}\text { Neutralized the IBMX-induced increase in } \\
\text { melanin content in B16-F10 cells by } \\
\text { inhibiting tyrosinase gene expression at the } \\
\text { level of transcription }\end{array}$ & Lee et al. (2015) [20] \\
\hline $\begin{array}{l}\text { Anti-inflammatory } \\
\text { effect in intestine }\end{array}$ & GC/MS & Leaves & Linalool & In vivo & $\begin{array}{l}\text { The suppression of the TLR4 pathway by } \\
\mathrm{CO} \text { and partly by the inhibitory effect of } \mathrm{CO} \\
\text { on the activity of xanthine oxidase }\end{array}$ & Lee et al. (2015) [27] \\
\hline Anti-tumor & NA & Leaves & Trans-cinnamaldehyde & In vitro & $\begin{array}{l}\text { Trans-cinnamaldehyde triggers suicidal } \\
\text { death oferythrocytes, i.e., cells devoid of } \\
\text { mitochondria and gene expression. }\end{array}$ & Theurer et al. (2013) [46] \\
\hline $\begin{array}{c}\text { Dietary supplements } \\
\text { and treatment of } \\
\text { hyperuricemia and } \\
\text { gout }\end{array}$ & GC-MS and GC-FID & Leaves & Cinnamaldehyde & In vitro & The xanthine oxidase inhibitory activity & Huang et al. (2018) [19] \\
\hline $\begin{array}{l}\text { Anti-hyperglycemic } \\
\text { and antioxidant } \\
\text { activities }\end{array}$ & $\begin{array}{c}\text { (MALDI/MS) (RP-HPLC) } \\
\text { /MS/MS }\end{array}$ & Twigs & Proanthocyanidin & In vitro & $\begin{array}{l}\text { The proanthocyanidins in CoTE mainly } \\
\text { consisted of (epi)catechin and contained at } \\
\text { least one A-type linkage. The inhibitory } \\
\text { activity of } \alpha \text {-glucosidase and } \alpha \text {-amylase }\end{array}$ & Lin et al. (2016) [21] \\
\hline
\end{tabular}


It was conveyed that C. osmophloeum comprised six chemotypes; cinnamaldehyde, cinnamaldehyde/cinnamyl acetate, cinnamyl acetate, linalool, camphor, and mixed types (Table 2). The chemical structures of cinnamaldehyde, cinnamyl acetate, linalool, and camphor are given in Figure 2. Most of the studies showed that the dominant chemical contents of the cinnamaldehyde type were cinammaldehyde/trans-cinnamaldehyde $[2,29,31-34,36,37,47,48]$, benzaldehyde $[32,33,37$, 48], benzenepropanal [37,47-49], and cinnamyl acetate/trans-cinnamyl acetate [2,29,36]. The cinnamaldehyde/cinnamyl acetate type encompassed cinnamyl acetate, trans-cinnamaldehyde, and benzenepropanal [34,48,49]. The cinnamyl acetate type included cinnamyl acetate [29,34], 2-methylbenzofuran, and geranyl acetate [34]. The linalool type contained linalool $[3,29,34,48]$ and cinnamaldehyde/trans-cinnamaldehyde [3,34]. The camphor type contained camphor/D-(+)-camphor and L-bornyl acetate $[29,34,36,48]$ and limonene [34,48]. The mixed type comprised spathulenol [24], neral [32,33], L-bornyl acetate/bornyl acetate [29,30,34,41,48], 1,8-cineol [24,32,33], T-cadinol, and $\alpha$-cadinol $[29,34,41,48]$.

Table 2. Chemotypes and chemical compositions of C. osmophloeum. All of the studies on C. osmophloeum chemical contents utilized leaf extracts, except number 48 (twig extract).

\begin{tabular}{|c|c|c|}
\hline No & Chemical Compositions & References \\
\hline \multicolumn{3}{|c|}{ Cinnamaldehyde type } \\
\hline 1 & Cinnamaldehyde, Geranyl acetate, Benzaldehyde. & $\begin{array}{l}\text { Chang et al. (2001), Wang et al. } \\
\text { (2005) [32,33] }\end{array}$ \\
\hline 2 & trans-Cinnamaldehyde, Benzenepropanal, 4-Allylanisole. & Chang et al. (2008) [31] \\
\hline 3 & $\begin{array}{l}\text { trans-Cinnamaldehyde, Cinnamyl acetate, } \\
\text { 3-Phenylpropionaldehyde. }\end{array}$ & Tung et al. (2010) [29] \\
\hline 4 & $\begin{array}{l}\text { trans-Cinnamaldehyde, Cinnamyl acetate, } \\
\text { 3-Phenylpropionaldehyde. }\end{array}$ & Tung et al. (2010) [29] \\
\hline 5 & $\begin{array}{c}\text { trans-Cinnamaldehyde, Cinnamyl acetate, } \\
\text { 3-Phenylpropionaldehyde. }\end{array}$ & Tung et al. (2010) [29] \\
\hline 6 & trans-Cinnamaldehyde, Cinnamyl acetate, 3-Pheaylpionaldehyde. & Wang et al. (2008) [2] \\
\hline 7 & $\begin{array}{l}\text { trans-Cinnamaldehyde, trans-Cinnamyl acetate, } \\
\text { 3-Phenylpropionaldehyde. }\end{array}$ & Hsu et al. (2012) [36] \\
\hline 8 & trans-Cinnamaldehyde, Benzenepropanal, Benzaldehyde. & $\begin{array}{l}\text { Yeh et al. (2013), Cheng (2008) } \\
{[37,49]}\end{array}$ \\
\hline 9 & trans-Cinnamaldehyde, Benzaldehyde, Benzenepropanal. & Yeh et al. (2013) [37] \\
\hline 10 & trans-Cinnamaldehyde, Benzaldehyde, Benzenepropanal. & Yeh et al. (2013) [37] \\
\hline 11 & trans-Cinnamaldehyde, Benzaldehyde, Benzenepropanal. & Yeh et al. (2013) [37] \\
\hline 12 & trans-Cinnamaldehyde, Linalool, trans-Cinnamyl acetate. & Yeh et al. (2013) [37] \\
\hline 13 & $\begin{array}{l}\text { trans-Cinnamaldehyde, Benzaldehyde, } \\
\text { 3-Phenylpropionaldehyde. }\end{array}$ & Huang et al. (2018) [19] \\
\hline 14 & trans-Cinnamaldehyde, trans-Cinnamyl acetate, Benzenepropanal. & Mdoe et al. (2014) [47] \\
\hline 15 & Cinnamaldehyde, Geranyl acetate, Benzaldehyde. & Wang et al. (2005) [33] \\
\hline 16 & trans-Cinnamaldehyde, Cinnamyl acetate, $\beta$-Caryophyllene. & Cheng et al. (2004) [48] \\
\hline 17 & trans-Cinnamaldehyde, Benzenepropanal, benzaldehyde. & Cheng et al. (2004) [48] \\
\hline 18 & trans-Cinnamaldehyde, Benzenepropanal, benzaldehyde. & Cheng et al. (2004) [48] \\
\hline 19 & $\begin{array}{c}\text { trans-Cinnamaldehyde, Benzenepropanal, } \\
\text { 4-Allylanisole. }\end{array}$ & Cheng et al. (2009) [50] \\
\hline 20 & trans-Cinnamaldehyde, Cinnamyl acetate, Bornyl acetate. & Cheng et al. (2006) [34] \\
\hline 21 & trans-Cinnamaldehyde, Benzenepropanal, Eugenol. & Cheng et al. (2006) [34] \\
\hline 22 & trans-Cinnamaldehyde, Benzenepropanal, Cinnamyl acetate. & Cheng et al. (2006) [34] \\
\hline \multicolumn{3}{|c|}{ Cinnamaldehyde/Cinnamyl acetate type } \\
\hline 23 & Cinnamyl acetate, trans-Cinnamaldehyde, Benzenepropanal. & Chang et al. (2008) [31] \\
\hline 24 & trans-Cinnamaldehyde, Cinnamyl acetate, Benzenepropanal. & Cheng et al. (2004) [48] \\
\hline 25 & Cinnamyl acetate, trans-Cinnamaldehyde, Camphene. & Cheng et al. (2004) [48] \\
\hline 26 & Cinnamyl acetate, trans-Cinnamaldehyde, Benzenepropanal. & Cheng et al. (2009) [50] \\
\hline 27 & trans-Cinnamaldehyde, Cinnamyl acetate, Benzenepropanal. & Cheng et al. (2006) [34] \\
\hline 28 & Cinnamyl acetate, trans-Cinnamaldehyde, Camphene. & Cheng et al. (2006) [34] \\
\hline
\end{tabular}


Table 2. Cont.

\begin{tabular}{|c|c|c|}
\hline No & Chemical Compositions & References \\
\hline \multicolumn{3}{|c|}{ Cinnamyl acetate type } \\
\hline 29 & Cinnamyl acetate, 2-Methylbenzofuran, Geranyl acetate. & Chang et al. (2008) [31] \\
\hline 30 & Cinnamyl acetate, trans-Cinnamaldehyde, Caryophyllene oxide. & Tung et al. (2010) [29] \\
\hline 31 & Cinnamyl acetate, 2-Methylbenzofuran, Geranyl acetate. & Cheng et al. (2009) [50] \\
\hline 32 & Cinnamyl acetate, 2-Methylbenzofuran, Geranyl acetate. & Cheng et al. (2006) [34] \\
\hline \multicolumn{3}{|c|}{ Linalool type } \\
\hline 33 & Linalool, trans-Cinnamaldehyde, Cinnamyl acetate. & Chang et al. (2008) [31] \\
\hline 34 & Linalool, $\beta$-Caryophyllene, 4-Allylanisole. & Tung et al. (2010) [29] \\
\hline 35 & Linalool, Cinnamaldehyde, 3-phenyl-2-propenal. & Lee et al. (2013) [3] \\
\hline 36 & Linalool, Citral, Coumarin. & Cheng et al. (2004) [48] \\
\hline 37 & $\begin{array}{c}\text { Linalool, trans-Cinnamaldehyde, } \\
\text { 4-Allylanisole. }\end{array}$ & Cheng et al. (2009) [50] \\
\hline 38 & Linalool, Coumarin, trans-Cinnamaldehyde. & Cheng et al. (2006) [34] \\
\hline \multicolumn{3}{|c|}{ Camphor type } \\
\hline 39 & Camphor, L-Bornyl acetate, (+)-Limonene. & Chang et al. (2008) [31] \\
\hline 40 & D-(+)-Camphor, L-Bornyl acetate, $\alpha$-Terpineol & Tung et al. (2010) [29] \\
\hline 41 & D-(+)-Camphor, L-Bornyl acetate, $\alpha$-Terpineol. & Hsu et al. (2012) [36] \\
\hline 42 & Camphor, bornyl acetate, Limonene. & Cheng et al. (2004) [48] \\
\hline 43 & Camphor, L-Bornyl acetate, (+)-Limonene. & Cheng et al. (2009) [50] \\
\hline 44 & Camphor, Bornyl acetate, Limonene. & Cheng et al. (2006) [34] \\
\hline \multicolumn{3}{|c|}{ Mixed type } \\
\hline 45 & Spathulenol, Linalool, $\alpha$-Terpineol. & Chang et al. (2008) [31] \\
\hline 46 & Neral, 1.8-Cineol, Linalool. & $\begin{array}{l}\text { Chang et al. (2001), Wang et al. } \\
\text { (2005) [32,33] }\end{array}$ \\
\hline 47 & L-Bornyl acetate, Caryophyllene oxide, $\gamma$-Eudesmol. & Tung et al. (2008) [30] \\
\hline 48 & L-Bornyl acetate, $\alpha$-Cadinol, T-Cadinol. & Tung et al. (2010) [29] \\
\hline 49 & L-bornyl acetate, T-Cadinol, $\alpha$-Cadinol. & Yu et al. (2014) [41] \\
\hline 50 & 1,8-cineole, spathulenol, santolina triene. & Chao et al. (2005) [24] \\
\hline 51 & T-Cadinol, $\alpha$-Cadinol., bornyl acetate. & Cheng et al. (2004) [48] \\
\hline 52 & Geranial, Neral, 1,8-Cineole. & Cheng et al. (2009) [50] \\
\hline 53 & T-Cadinol, $\alpha$-Cadinol, bornyl acetate. & Cheng et al. (2006) [34] \\
\hline
\end{tabular}

(a)<smiles>O=C/C=C/c1ccccc1</smiles>

(b)<smiles>CC(=O)OC/C=C/c1ccccc1</smiles>

(c)

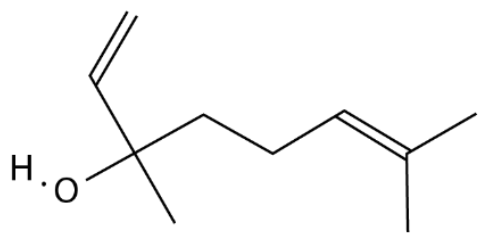

(d)

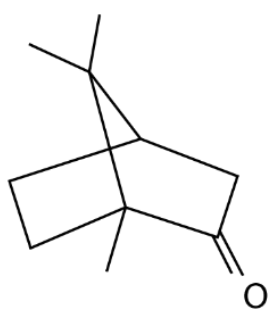

Figure 2. Chemical structures of Cinnamomum osmophloeum chemotypes: (a) cinnamaldehyde, (b) cinnamyl acetate, (c) linalool, and (d) camphor. 


\subsubsection{Anti-Inflammatory and Wound Repair Activities}

Numerous studies reported the anti-inflammatory effect of C. osmophloeum [24-26,28-30,40] and they have been applied to the medical treatment of animal organs, such as endotoxin-induced intestinal injury [27], pancreas protection [3], and lipopolysaccharide/D-galactosamine (LPS/D-GaIN)-induced acute hepatitis [6]. Some of these studies identified the specific constituents of C. osmophloeum that accounted for the anti-inflammatory effect $[23,26,28,30,40]$. For example, Kaempferitin, a constituent of $C$. osmophloeum, was reported to be an anti-inflammatory that could down-regulate the extracellular LDL-R (Low-Density Lipoprotein-Receptor), followed by ameliorating subsequent chronic inflammation-related diabetes mellitus [26]. Several constituents of C. osmophloeum, including trans-cinnamaldehyde, caryophyllene oxide, L-borneol, L-bornyl acetate, eugenol, $\beta$-caryophyllene, E-nerolidol, and cinnamyl, were demonstrated to be anti-inflammatory, which could suppress the synthesis of nitric oxide (NO) by LPS-stimulated macrophages through an identical mechanism $[29,30]$. Cinnamaldehyde was verified as the major anti-inflammation constituent whose activities were derived from the in vitro synthesis of LPS-stimulated macrophages [23].

Other constituents such as Kaempferol glycosides were associated with nitric oxide inhibitory activities [28]. In certain studies, linalool extracted from C. osmophloeum exhibited a protective effect on the pancreas by ameliorating pancreatic levels of interleukin (IL)-1 $\beta$ and nitric oxide [3], which play an important role in the prevention of LPS-induced inflammation in vivo [40].

C. osmophloeum has been used as a tyrosinase suppressor, which exhibited a substantial effect on wound repair. This phenomenon occurred through the inhibition of tyrosinase activity and reduced melanin content. Lee et al. carried out an animal experiment and explored the role of C. osmophloeum in wound repair and as an anti-oxidative agent. They evaluated a wound size assay, which revealed a decrease in the wound area by day 5 [20].

In light of the specific activities of the constituents of $C$. osmophloeum, it is noteworthy to mention that one specific and major constituent (flavanol glycosides) with outstanding properties was involved in inhibiting the production of NO and cytokines (TNF-a and IL-12), from LPS/IFNc-activated macrophages (inhibition of inflammatory activities) [25]. An additional study revealed the in vitro inhibitory effect of IL-1â and IL-6 production resulting from the 21 constituents of C. osmophloeum (cell-mediated immune response) observed [24]. Anti-inflammatory activity studies of C. osmophloeum have also been applied systemically in specific disease treatment [3,22,27,40]. Numerous mechanisms of inhibiting inflammation, including the compositional contents, mechanisms, anatomical parts, and promising investigations, have also been reported elsewhere [22-26,28,40,45].

\subsubsection{Antimicrobial Activities}

The literature survey indicated that several pathogenic bacteria, including Escherichia coli, Pseudomonas aeruginosa, Enterococcus faecalis, Staphylococcus aureus, Staphylococcus epidermidis, methicillin-resistant Staphylococcus aureus (MRSA), Klebsiella pneumoniae, Salmonella sp., and Vibrio parahaemolyticus have been used to investigate the antibacterial activity of C. osmophloeum [30]. For constituents of C. osmophloeum, the order of antibacterial activities was in the following sequence: cinnamaldehyde $>$ cinnamic acid $>$ cinnamyl alcohol $>$ cinnamyl acetate. Cinnamaldehyde has been used as a bactericidal agent of Legionella pneumophila in vitro [31]. Two investigations confirmed that $C$. osmophloeum possesses antibacterial activities in both Gram-negative and Gram-positive bacteria [31,32]. Hence, further study should be carried out to examine animals infected by a specific group or both Gram-negative and Gram-positive bacteria.

C. osmophloeum also has antifungal properties in rot fungi, such as Coriolus versicolor, Lenzites betulina, Pycnoporus coccineus, Trichaptum abietinum, Oligoporus lowe, Laetiporus sulphureus, Antrodia taxa, Fomitopsis pinicola, and Phaeolus schweinitzii [33,34]. 


\subsubsection{Antioxidant Activities}

As one of the biomaterials commonly used for traditional medical therapy, C. osmophloeum has been reported to be antioxidative, and its properties encompassing other medical-biological effects have been assessed systematically and independently by researchers worldwide [18,20,35-37,41].

For the analysis of anti-oxidant activities, both in vitro [18,20,35,37,41] and in vivo [35,36] investigations have been carried out. The investigations consisted of several studies: a 2,2-diphenyl-1-picrylhydrazyl (DPPH) scavenging activity assay [18,20,35], a superoxide radical scavenging assay (NBT Assay), reducing power, lipid peroxidation using mouse brain homogenates, the metal chelating ability, photochemiluminescence (PCL) [35], and an oxidative stress resistance assay [36]. Several constituents of C. osmophloeum comprising trans-cinnamaldehyde [36], alloaromadendrene [41], and kaempferol-7-O-rhamnoside [35] were proven to possess antioxidant properties.

DPPH and NBT Assays reported the antioxidant activities of kaempferol-7-O-rhamnoside [35]. The content had an excellent inhibitory effect on rat aldose reductase [51]. The flavonoid glycoside was proven to be the key antioxidant in a C. osmophloeum twig ethanolic extract [35]. These activities are associated with beneficial health effects. Therefore, cinnamomum has been widely used for its medicinal purpose and in nutritional food [52].

\subsubsection{Antidyslipidemic Activities}

The activity of $C$. osmophloeum in lowering the cholesterol level was investigated by Lin et al. They showed that both Kaempferol and kaempferitrin from C. osmophloeum have antidyslipidemic activity [38]. Furthermore, the S-(p)-linalool in C. osmophloeum was also reported to have hypolipidemic activity by inhibiting the accumulation of body fat through downregulating adipocyte differentiation [39]. Two in vivo studies disclosed encouraging results demonstrating that S-(p)-linalool was effective at cutting lipid accumulation. They also showed that low-density lipoprotein (LDL) was significantly decreased compared to high-density lipoprotein (HDL) [38,39].

\subsubsection{Anti-Hyperglycemic Activities}

Diabetes mellitus (DM) has become a serious medical problem. Numerous studies have been conducted by adapting natural materials as DM therapy. Among these bio-resource candidates, $C$. osmophloeum is one of the promising candidates. Proanthocyanidin and tannin from C. osmophloeum may possess anti-hyperglycemic activity [21]. CoTE (C. osmophloeum twig extracts) showed protein tyrosine phosphatase 1B inhibitory (PTP1B) activity to improve the insulin or leptin resistance [18]. Linalool, the constituent of the essential oil of $C$. Osmophloeum, might ameliorate the pancreatic values of thiobarbituric acid reactive substances. The activities of superoxide dismutase and glutathione reductase ameliorated pancreatic levels of IL-1 $\beta$ and NO in vivo in streptozotocin-diabetes mellitus (STZ-DM)) animals [3]. It was reported that a higher degree of polymerization of proanthocyanidins correlates with the inhibitory activity of $\alpha$-glucosidase and $\alpha$-amylase [21]. The studies explored leaves and twigs with different contents for decreasing the blood glucose level and treating diabetes mellitus. The results indicated that the leaves were more effective than the twigs, which contained less linalool. Moreover, in a practical sense, the leaves were much easier to preserve than twigs.

\subsubsection{Effects on the Cardiovascular System}

Cinnamaldehyde was shown to be one of the protective ingredients for cerebral microvascular endothelial cells in mice induced by aortic banding (AB) by reducing IL- $1 \beta$-induced cyclooxygenase- 2 (COX-2) activity [53]. In addition, the protective role of cinnamaldehyde in cardiac hypertrophy induced by $\mathrm{AB}$ was related to its regulatory effect on the ERK1/2 signaling pathway [7]. The effect on the cardiovascular system was related to the anti-inflammatory mechanism $[7,53]$. The authors introduced cinnamaldehyde as a major compound extracted from C. osmophloeum and it was bought from Sigma-Aldrich (USA). It was discussed that Cinnamomum cassia (C. cassia) would be a potential 
drug for cardiovascular disease [7]. Unreliable cinnamon species (C. cassia or C. osmophloeum) used in the report would be a critical issue to clarify because the authors may have been inconsistent in discussing the species of cinnamon.

\subsubsection{Effect on Renal Disease and Anti-Hyperuricemia}

It was reported that cinnamaldehyde in C. osmophloeum successfully inhibited the high glucose-induced hypertrophy of renal interstitial fibroblasts, as indicated by the decreased cell size; the falling cellular hypertrophy index; and the descending protein levels of collagen IV, fibronectin, and $\alpha$-smooth muscle actin [4]. In order to decrease the level of uricemia, several in vivo study reports confirmed the proposed mechanisms [2,5]. The cinnamaldehyde type of $C$. osmophloeum leaf oil demonstrated anti-hyperuricemia effects through its xanthine oxidase inhibitory activity. Xanthine oxidase can catalyze the oxidation of hypoxanthine/xanthine to produce uric acid. Gout and hyperuricemia are caused by an excessive accumulation of uric acid $[2,19]$.

\subsubsection{Anti-Tumor and Anti-Cancer Activity}

Trans-cinnamaldehyde, a bioactive content of C. osmophloeum, showed an inhibition of tumor growth $[46,54,55]$. It could stimulate $\mathrm{Ca}^{2+}$ entry with subsequent cell membrane scrambling and cell shrinkage, hallmarks of eryptosis, and the suicidal death of erythrocytes [46]. Trans-cinnamaldehyde exposure induced cell death via caspase-dependent and -independent pathways resulting from the depletion or induction of ROS [54]. Lignan ester, one of the C. osmophloeum constituents, was shown to be a possible anticancer compound (liver and oral cancer). The cytotoxicity had a significant effect on human liver cancer (HepG2 and Hep3B) and oral cancer (Ca9-22) cells [42].

\subsection{Potential Use of C. osmophloeum for the Treatment of Oral Mucositis (OM)}

The current protocols of medicine for chemotherapy are associated with oral mucositis. Cytarabine, high-dose 5-fluororacil, alkylating agents, and platinum-based compounds are highly associated with the incidence of oral mucositis. Actinomycin D, amsacrin, bleomycin, busulfan, capecitabine, carboplatin, chlorambucil, cisplatin, cytarabine, docetaxel, doxorubicin, etoposide, floxuridine, ifofsamide, irinotecan, leucovorin, methotrexate, mitoxantron, oxaliplatin, paclitaxel, plicamycin, tioguanin, vinblastine, vincristine, vindecine, and vinorelbine (the protocol can be combined) are the medicines used for chemotherapy and are reported to lead to the development of oral mucositis $[56,57]$. In order to prevent oral mucositis, the Multinational Association of Supportive Care in Cancer (MASCC) and International Society of Oral Oncology (ISOO) help clinics by comprising Clinical Practice Guidelines for Oral Mucositis [58]. The recommendations are comprised of basic oral care, growth factors and cytokines, anti-inflammatory agents, laser and other light therapy, cryotherapy, and natural and miscellaneous agents (Table 3). Köstler et al. provided several experimental approaches to treat oral mucositis; they included locally applied non-pharmacological methods, anti-inflammatory and mucosa protectant agents, cytokines, granulocyte colony-stimulating factor (G-CSF, filgrastim) and granulocyte-macrophage colony-stimulating factor (GM-CSF, molgramostim), antiseptic agents, corticosteroids, mouth-coating agents, and dexpanthenol [57]. 
Table 3. Interventions to prevent oral mucositis (clinical practice guidelines) proposed by the Multinational Association of Supportive Care in Cancer (MASCC) and International Society of Oral Oncology (ISOO).

\begin{tabular}{|c|c|c|c|}
\hline Intervention & Protocol & Population & $\begin{array}{l}\text { Evidence of } \\
\text { Effectiveness }\end{array}$ \\
\hline Basic oral care & $\begin{array}{l}\text { Tooth brushing, flossing, and one } \\
\text { mouth rinse }\end{array}$ & $\begin{array}{l}\text { All age groups and across all cancer } \\
\text { treatment modalities }\end{array}$ & Not strong evidence \\
\hline $\begin{array}{l}\text { Laser and other light } \\
\text { therapy }\end{array}$ & Low-level laser therapy (LLLT) & $\begin{array}{c}\text { Patients receiving } \\
\text { high-dose chemotherapy for HSCT with } \\
\text { or without } \\
\text { total body irradiation }\end{array}$ & Strong evidence \\
\hline
\end{tabular}

The study of C. osmophloeum and/or its constituents in OM are limited. In one study, the effect of cinnamaldehyde on oral mucositis and an evaluation of the salivary total antioxidant capacity of gamma-irradiated rats were carried out. The saliva samples were taken from the rats in triplicate [59]. In order to evaluate the consequences and severity of mucositis, the conditions of the oral cavity were assessed by using Parkin's clinical scale, where 0 represents normal mucosa, 0.5 indicates normally pink mucosa, 1 stands for minor red mucosa, 2 is severe red mucosa, 3 is local desquamation, 4 describes exudation and crust around less than half of the lip area, and 5 characterizes exudation and crust for more than half of the lip area [60]. The authors concluded that the clinical effects in the intervention group seemed to be due to the antioxidant, antibacterial, and anti-inflammatory effects of cinnamaldehyde. It is noteworthy to mention that through anti-inflammation and antioxidant mechanisms, cinnamaldehyde would delay the onset of oral mucositis. Moreover, alteration in the oral microflora of existing bacteria in the fourth phase (ulceration phase) could exacerbate the severity of mucositis, whereas cinnamaldehyde alleviated oral mucositis via its antibacterial properties [59]. A recent investigation reported the effect of cinnamon bark fractions (an essential oil and an aqueous extract) on Candida albicans growth inhibition (growth, biofilm formation, and adherence properties) and oral epithelial cells (barrier integrity and inflammatory response) [61]. The anti-adherence and anti-inflammatory properties of proanthocyanidins, a family of polyphenols containing flavan-3-ol oligomers and polymers, are used to treat oral infections [61,62]. The two pro-inflammatory cytokines, IL-6 and IL-8, which serve as important cytokines in the development of oral mucositis, were reduced by an aqueous extract enriched with proanthocyanidins of the cinnamon fraction. This shows that the cinnamon presented in the study may be a promising agent in the alleviation of oral mucositis [61].

Other biomaterials or herbal products, such as Aloe vera, Acacia catechu, Chamomile, Hangeshashinto, indigowood root (Isatis indigotica Fort.), honey, Traumeel S, water grass decoction, and Weleda Ratanhia, also showed similar effects on the alleviation of OM via anti-inflammation activities [17,63-72]. The bioactive properties of the yarrow plant (Achillea mileofolium), honey, Callendula officinalis flowers, Hipophae rhamnoides L. plant, Chamomile, and Aloe vera were associated with antioxidant, anti-inflammatory, antibacterial, and wound healing effects of oral mucositis therapy (Table 4) [64-66,72-77]. Similar to the advantages of the medical-biological activities of these herbal agents, C. osmophloeum would provide an identical mechanism for relieving oral mucositis. 
Table 4. Bioactive properties of natural agents for oral mucositis therapy.

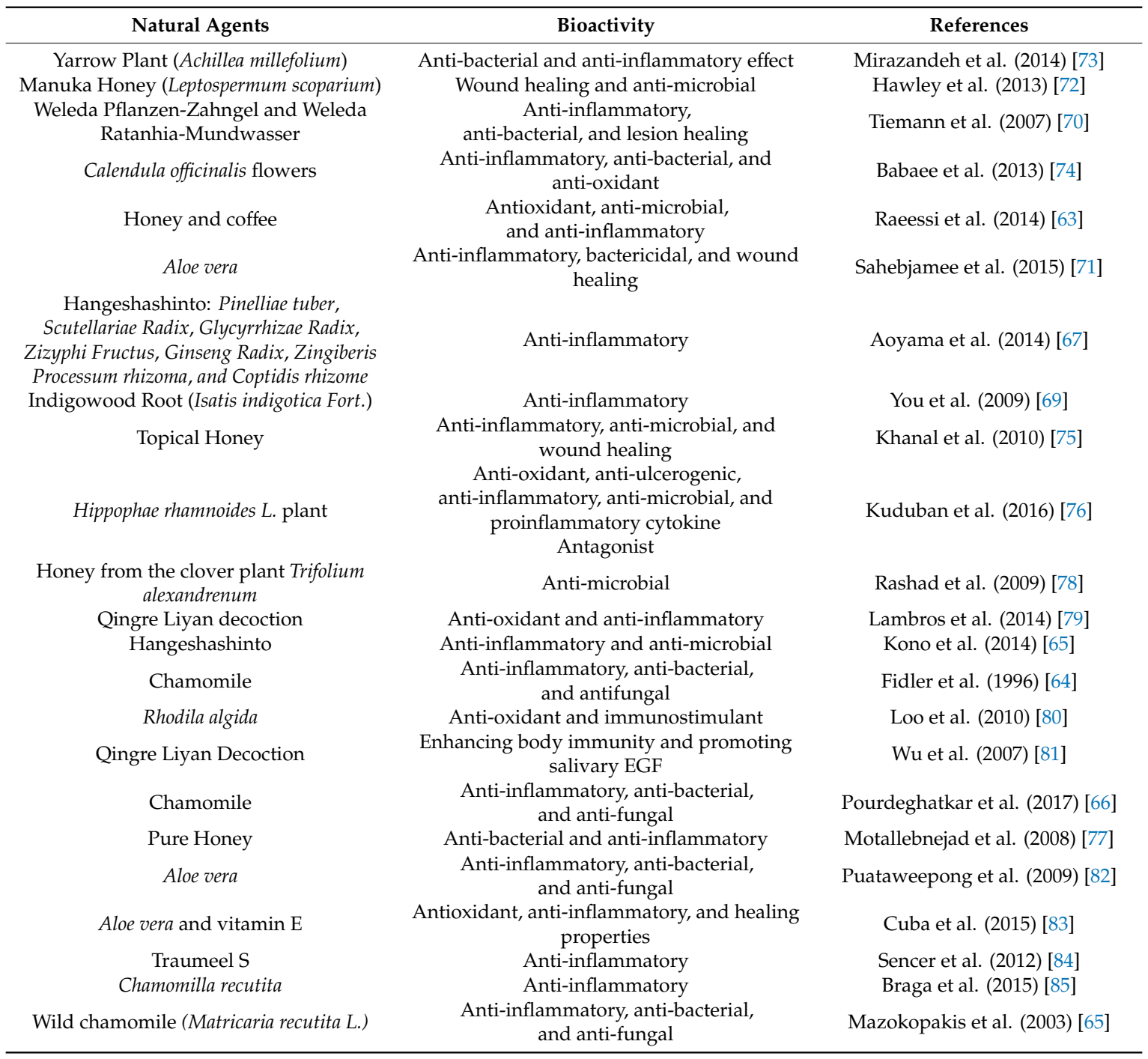

According to antibacterial mechanisms, several studies demonstrated bacterial changes due to radiotherapy and/or chemotherapy [85]. The bacteria were Gemella haemolysans, Streptococcus mitis [86], Escherichia coli, Pseudomonas aeruginosa, Enterobacter sp., Klebsiella pneumonia [87], Staphylococcus aureus, Staphylococcus epidermidis, Parvimonasmicra, Fusobacterium nucleatum, Treponema denticola, C. glabrata, C. kefyr [88], and Porphyromonas gingivalis [89]. Among these bacteria, C. osmophloeum has been confirmed to possess the antibacterial properties of Pseudomonas aeruginosa, Staphylococcus aureus, and Staphylococcus epidermidis (Figure 3) [32].

Flavanoid-rich fractions containing kaempferitin in Bauhinia forficata leaves have been investigated and shown to be effective ingredients for preventing the intestinal toxic effects of irinotecan chemotherapy. It was stated that kaempferitin, as one of the major active contents of C. osmophloeum, has been tested to prevent or reduce the severity of intestinal mucositis $[26,90]$. The chemotherapy drug 5-Fluororacil possesses side effects (i.e., induces mucositis manifestations in oral and gastrointestinal after chemotherapy). Chimonatus Nitens var. salicifolius aqueous extract contains three flavonoid contents: quercetin, kaempferol, and rutin, which might have an anti-inflammatory effect on gastrointestinal mucositis [91]. Kaempferol, cinamic acid, and nine other constituents obtained in mucoadhesive propolis agent have been proven to be effective in reducing radiation-induced oral mucositis. A clinical study of 24 patients revealed that mucositis only developed in two patients and each developed grade 
1 mucositis and grade 2 mucositis, respectively; however, in the remaining 20 patients, mucositis did not develop [92].
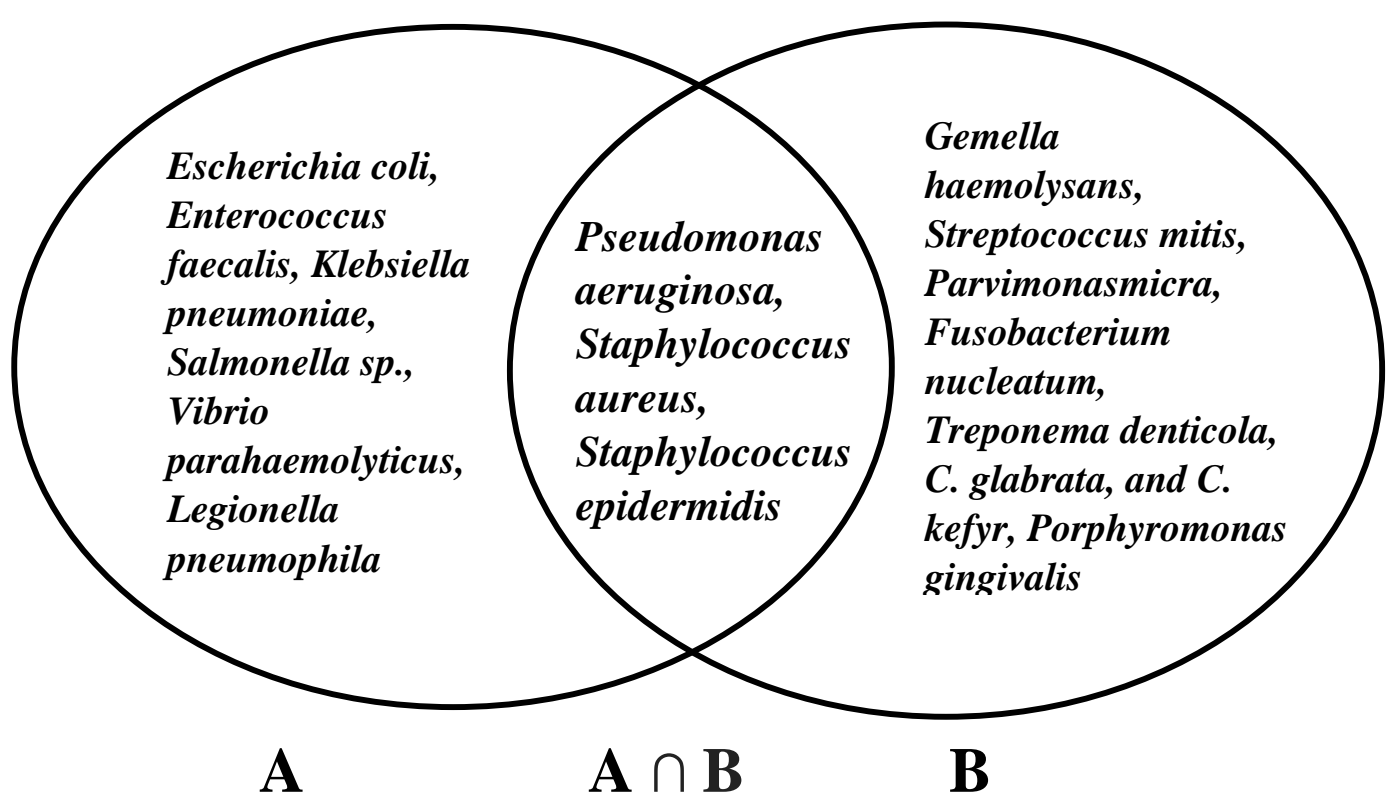

Figure 3. Antibacterial properties of C. osmophloeum (A) and bacterial infection of oral mucositis (B).

Previous studies investigated the potential of C. osmophloeum to reduce oral mucositis. Nonetheless, C. osmopohloeum, which is a species of cinnamon, faces challenges in its use as an oral treatment. In addition, this review has several limitations. First, there are limited data on the medical-biological effects of C. osmophloeum and its potential use in oral mucositis therapy. Secondly, the reported events related to oral stomatitis allergy induced by cinnamon should be a concern [93-95]. In summary, $C$. osmophloeum and its constituent are anticipated to be effective and efficient in reducing the severity of OM by preventing secondary bacterial infection through their bactericidal activity, preventing the development of the second phase of OM (the primary damage response) or interrupting the third phase in which pro-inflammatory cytokines could enhance and accelerate the process of wound healing (Figure 4).

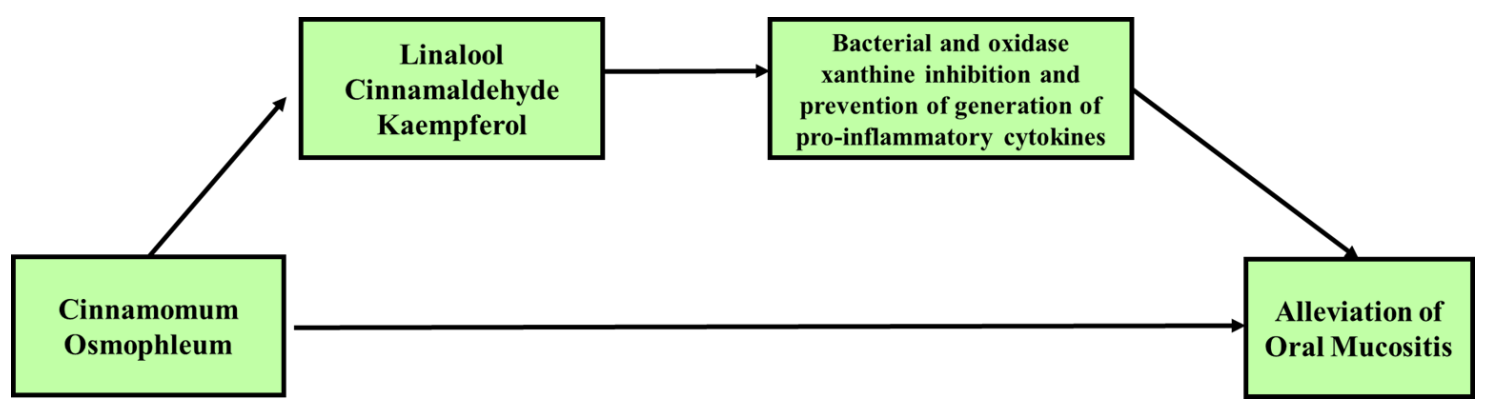

Figure 4. Proposed potential use of $C$. osmophloeum in the alleviation of oral mucositis (OM). C. osmophloeum ameliorated oxidative stress and pro-inflammation through its constituents. Several studies have investigated the anti-inflammation, antibacterial, and antioxidant activities. The review of medical-biological activities showed that $C$. osmophloeum and its constituents inhibit the pro-inflammatory response. C. osmophloeum potentially prevents the second phase of oral mucositis (the primary damage response) or may intercept in the third phase, with pro-inflammatory cytokines providing a positive reaction to enhance and accelerate the process of wound healing. C. osmophloeum was also confirmed to be bactericidal and inhibit bacteria which can reduce the severity of oral mucositis or secondary bacterial infection. 


\section{Conclusions}

In conclusion, in vitro and animal studies have revealed the various medical-biological activities of C. osmophloeum encompassing anti-inflammatory, antibacterial, antioxidant, anti-tumor and anti-cancer, anti-hyperglycemic, anti-hyperuricemia, and antidyslipidemic activities and the effect on the cardiovascular system that have been used for renal disease therapy. Various chemical contents identified in C. osmophloeum contribute to its valuable medical bioactivities. Several medical-biological activities are attributed to the active ingredients of $C$. osmophloeum for OM therapy. The key to OM alleviation could be the anti-inflammatory effect of $C$. osmophloeum, as the activation of several transcription factors might release the inflammatory reaction in the second phase of OM. The antibacterial and antioxidant properties of $\mathrm{CO}$ might also alleviate OM. These effects might occur during the first phase of $\mathrm{OM}$, preventing the generation of reactive oxygen species, or in the fourth phase, inhibiting colonized bacteria. It was suggested that bacterial cell wall products could be prevented from entering the oral submucosa.

Author Contributions: A.B. and S.-C.L. conceived and designed the work, A.B. and V.N. collected the data (computerized search), P.-C.Y. and C.-T.L. verified the analytical methods, A.B. and S.-C.L. organized the paper, and P.-C.Y. and S.-C.L. analyzed the findings of this work. All authors discussed the results and contributed to the final manuscript. All authors have read and agreed to the published version of the manuscript.

Funding: The authors acknowledge the financial support by a grant from the Ministry of Science and Technology, Taiwan, ROC (NSC 101-2324-B-040-008-MY3).

Conflicts of Interest: The authors declare no conflicts of interest. The funders had no role in the design of the study; in the collection, analyses, or interpretation of data; in the writing of the manuscript, or in the decision to publish the results.

\section{References}

1. Ribeiro-Santos, R.; Andrade, M.; Madella, D.; Martinazzo, A.P.; de Aquino Garcia Moura, L.; de Melo, N.R.; Sanches-Silva, A. Revisiting an ancient spice with medicinal purposes: Cinnamon. Trends Food Sci. Technol. 2017, 62, 154-169. [CrossRef]

2. Wang, S.Y.; Yang, C.W.; Liao, J.W.; Zhen, W.W.; Chu, F.H.; Chang, S.T. Essential oil from leaves of Cinnamomum osmophloeum acts as a xanthine oxidase inhibitor and reduces the serum uric acid levels in oxonate-induced mice. Phytomedicine 2008, 15, 940-945. [CrossRef] [PubMed]

3. Lee, S.-C.; Xu, W.-X.; Lin, L.-Y.; Yang, J.-J.; Liu, C.-T. Chemical Composition and Hypoglycemic and Pancreas-Protective Effect of Leaf Essential Oil from Indigenous Cinnamon (Cinnamomum osmophloeum Kanehira). J. Agric. Food Chem. 2013, 61, 4905-4913. [CrossRef]

4. Chao, L.K.; Chang, W.T.; Shih, Y.W.; Huang, J.S. Cinnamaldehyde impairs high glucose-induced hypertrophy in renal interstitial fibroblasts. Toxicol Appl. Pharm. 2010, 244, 174-180. [CrossRef] [PubMed]

5. Huang, J.-S.; Lee, Y.-H.; Chuang, L.-Y.; Guh, J.-Y.; Hwang, J.-Y. Cinnamaldehyde and Nitric Oxide Attenuate Advanced Glycation End Products-Induced the JAK/STAT Signaling in Human Renal Tubular Cells. J. Cell. Biochem. 2015, 116, 1028-1038. [CrossRef]

6. Tung, Y.-T.; Huang, C.-C.; Ho, S.-T.; Kuo, Y.-H.; Lin, C.-C.; Lin, C.-T.; Wu, J.-H. Bioactive Phytochemicals of Leaf Essential Oils of Cinnamomum osmophloeum Prevent Lipopolysaccharide/d-Galactosamine (LPS/d-GalN)-Induced Acute Hepatitis in Mice. J. Agric. Food Chem. 2011, 59, 8117-8123. [CrossRef]

7. Yang, L.; Wu, Q.-Q.; Liu, Y.; Hu, Z.-F.; Bian, Z.-Y.; Tang, Q.-Z. Cinnamaldehyde attenuates pressure overload-induced cardiac hypertrophy. Int. J. Clin. Exp. Pathol. 2015, 8, 14345-14354.

8. Raber-Durlacher, J.E.; Elad, S.; Barasch, A. Oral mucositis. Oral Oncol. 2010, 46, 452-456. [CrossRef]

9. Elting, L.S.; Cooksley, C.D.; Chambers, M.S.; Garden, A.S. Risk, Outcomes, and Costs of Radiation-Induced Oral Mucositis Among Patients With Head-and-Neck Malignancies. Int. J. Radiat. Oncol. Biol. Phys. 2007, 68, 1110-1120. [CrossRef]

10. Elting, L.S.; Keefe, D.M.; Sonis, S.T.; Garden, A.S.; Spijkervet, F.K.L.; Barasch, A.; Tishler, R.B.; Canty, T.P.; Kudrimoti, M.K.; Vera-Llonch, M.; et al. Patient-reported measurements of oral mucositis in head and neck cancer patients treated with radiotherapy with or without chemotherapy. Cancer 2008, 113, 2704-2713. [CrossRef] 
11. Murphy, B.A.; Beaumont, J.L.; Isitt, J.; Garden, A.S.; Gwede, C.K.; Trotti, A.M.; Meredith, R.F.; Epstein, J.B.; Le, Q.-T.; Brizel, D.M.; et al. Mucositis-Related Morbidity and Resource Utilization in Head and Neck Cancer Patients Receiving Radiation Therapy With or Without Chemotherapy. J. Pain Symptom Manag. 2009, 38, 522-532. [CrossRef] [PubMed]

12. Lalla, R.V.; Sonis, S.T.; Peterson, D.E. Management of oral mucositis in patients who have cancer. Dent. Clin. North. Am. 2008, 52, 61-viii. [CrossRef] [PubMed]

13. Sonis, S.; Treister, N. Oral mucositis. In Oral complications of cancer and its management, 1st ed.; Davies, A., Epstein, J., Eds.; Oxford Universirty Press: Oxford, UK; New York, NY, USA, 2010; Volume 1, pp. 141-148.

14. Sonis, S.T. Pathobiology of oral mucositis: Novel insights and opportunities. J. Supportive Oncol. 2007, 5, 3-11.

15. Sonis, S.T. New thoughts on the initiation of mucositis. Oral Dis. 2010, 16, 597-600. [CrossRef] [PubMed]

16. Sonis, S.T. The pathobiology of mucositis. Nat. Rev. Cancer 2004, 4, 277-284. [CrossRef] [PubMed]

17. Baharvand, M.; Jafari, S.; Mortazavi, H. Herbs in Oral Mucositis. J. Clin. Diagn Res. 2017, 11, ZE05-ZE11. [CrossRef]

18. Lin, G.M.; Chen, Y.H.; Yen, P.L.; Chang, S.T. Antihyperglycemic and antioxidant activities of twig extract from Cinnamomum osmophloeum. J. Tradit Complement. Med. 2016, 6, 281-288. [CrossRef]

19. Huang, C.-Y.; Yeh, T.-F.; Hsu, F.-L.; Lin, C.-Y.; Chang, S.-T.; Chang, H.-T. Xanthine Oxidase Inhibitory Activity and Thermostability of Cinnamaldehyde-Chemotype Leaf Oil of Cinnamomum osmophloeum Microencapsulated with $\beta$-Cyclodextrin. Molecules 2018, 23, 1107. [CrossRef]

20. Lee, M.-G.; Kuo, S.-Y.; Yen, S.-Y.; Hsu, H.-F.; Leung, C.-H.; Ma, D.-L.; Wen, Z.-H.; Wang, H.-M.D. Evaluation of Cinnamomum osmophloeum Kanehira Extracts on Tyrosinase Suppressor, Wound Repair Promoter, and Antioxidant. Sci. World J. 2015, 2015, 7. [CrossRef]

21. Lin, G.-M.; Lin, H.-Y.; Hsu, C.-Y.; Chang, S.-T. Structural characterization and bioactivity of proanthocyanidins from indigenous cinnamon (Cinnamomum osmophloeum). J. Sci. Food Agric. 2016, 96, 4749-4759. [CrossRef]

22. Rao, Y.K.; Fang, S.-H.; Tzeng, Y.-M. Evaluation of the anti-inflammatory and anti-proliferation tumoral cells activities of Antrodia camphorata, Cordyceps sinensis, and Cinnamomum osmophloeum bark extracts. J. Ethnopharmacol. 2007, 114, 78-85. [CrossRef] [PubMed]

23. Chao, L.K.; Hua, K.-F.; Hsu, H.-Y.; Cheng, S.-S.; Lin, I.F.; Chen, C.-J.; Chen, S.-T.; Chang, S.-T. Cinnamaldehyde inhibits pro-inflammatory cytokines secretion from monocytes/macrophages through suppression of intracellular signaling. Food Chem. Toxicol. 2008, 46, 220-231. [CrossRef] [PubMed]

24. Chao, L.K.; Hua, K.-F.; Hsu, H.-Y.; Cheng, S.-S.; Liu, J.-Y.; Chang, S.-T. Study on the Antiinflammatory Activity of Essential Oil from Leaves of Cinnamomum osmophloeum. J. Agric. Food Chem. 2005, 53, 7274-7278. [CrossRef] [PubMed]

25. Fang, S.-H.; Rao, Y.K.; Tzeng, Y.-M. Inhibitory effects of flavonol glycosides from Cinnamomum osmophloeum on inflammatory mediators in LPS/IFN- $\gamma$-activated murine macrophages. Bioorganic Med. Chem. 2005, 13, 2381-2388. [CrossRef] [PubMed]

26. Ku, W.-c.; Chang, Y.-l.; Wu, S.-f.; Shih, H.-n.; Tzeng, Y.-m.; Kuo, H.-r.; Chang, K.-m.; Agrawal, D.C.; Liu, B.-l.; Chang, C.-a.; et al. A comparative proteomic study of secretomes in kaempferitrin-treated CTX TNA2 astrocytic cells. Phytomedicine 2017, 36, 137-144. [CrossRef]

27. Lee, S.-C.; Hsu, J.-S.; Li, C.-C.; Chen, K.-M.; Liu, C.-T. Protective Effect of Leaf Essential Oil from Cinnamomum osmophloeum Kanehira on Endotoxin-Induced Intestinal Injury in Mice Associated with Suppressed Local Expression of Molecules in the Signaling Pathways of TLR4 and NLRP3. PLoS ONE 2015, 10, e0120700. [CrossRef]

28. Lin, H.-Y.; Chang, S.-T. Kaempferol glycosides from the twigs of Cinnamomum osmophloeum and their nitric oxide production inhibitory activities. Carbohydr. Res. 2012, 364, 49-53. [CrossRef]

29. Tung, Y.T.; Yen, P.L.; Lin, C.Y.; Chang, S.T. Anti-inflammatory activities of essential oils and their constituents from different provenances of indigenous cinnamon (Cinnamomum osmophloeum) leaves. Pharm. Biol. 2010, 48, 1130-1136. [CrossRef]

30. Tung, Y.-T.; Chua, M.-T.; Wang, S.-Y.; Chang, S.-T. Anti-inflammation activities of essential oil and its constituents from indigenous cinnamon (Cinnamomum osmophloeum) twigs. Bioresour. Technol. 2008, 99, 3908-3913. [CrossRef]

31. Chang, C.W.; Chang, W.L.; Chang, S.T.; Cheng, S.S. Antibacterial activities of plant essential oils against Legionella pneumophila. Water Res. 2008, 42, 278-286. [CrossRef] 
32. Chang, S.-T.; Chen, P.-F.; Chang, S.-C. Antibacterial activity of leaf essential oils and their constituents from Cinnamomum osmophloeum. J. Ethnopharmacol. 2001, 77, 123-127. [CrossRef]

33. Wang, S.-Y.; Chen, P.-F.; Chang, S.-T. Antifungal activities of essential oils and their constituents from indigenous cinnamon (Cinnamomum osmophloeum) leaves against wood decay fungi. Bioresour. Technol. 2005, 96, 813-818. [CrossRef] [PubMed]

34. Cheng, S.-S.; Liu, J.-Y.; Hsui, Y.-R.; Chang, S.-T. Chemical polymorphism and antifungal activity of essential oils from leaves of different provenances of indigenous cinnamon (Cinnamomum osmophloeum). Bioresour. Technol. 2006, 97, 306-312. [CrossRef] [PubMed]

35. Chua, M.T.; Tung, Y.T.; Chang, S.T. Antioxidant activities of ethanolic extracts from the twigs of Cinnamomum osmophloeum. Bioresour Technol 2008, 99, 1918-1925. [CrossRef] [PubMed]

36. Hsu, F.-L.; Li, W.-H.; Yu, C.-W.; Hsieh, Y.-C.; Yang, Y.-F.; Liu, J.-T.; Shih, J.; Chu, Y.-J.; Yen, P.-L.; Chang, S.-T.; et al. In Vivo Antioxidant Activities of Essential Oils and Their Constituents from Leaves of the Taiwanese Cinnamomum osmophloeum. J. Agric. Food Chem. 2012, 60, 3092-3097. [CrossRef] [PubMed]

37. Yeh, H.-F.; Luo, C.-Y.; Lin, C.-Y.; Cheng, S.-S.; Hsu, Y.-R.; Chang, S.-T. Methods for Thermal Stability Enhancement of Leaf Essential Oils and Their Main Constituents from Indigenous Cinnamon (Cinnamomum osmophloeum). J. Agric. Food Chem. 2013, 61, 6293-6298. [CrossRef]

38. Lin, T.-Y.; Liao, J.-W.; Chang, S.-T.; Wang, S.-Y. Antidyslipidemic Activity of Hot-water Extracts from Leaves of Cinnamomum osmophloeum Kaneh. Phytother. Res. 2011, 25, 1317-1322. [CrossRef]

39. Cheng, B.H.; Sheen, L.Y.; Chang, S.T. Hypolipidemic effects of S-(+)-linalool and essential oil from Cinnamomum osmophloeum ct. linalool leaves in mice. J. Tradit Complement. Med. 2018, 8, 46-52. [CrossRef]

40. Lee, S.-C.; Wang, S.-Y.; Li, C.-C.; Liu, C.-T. Anti-inflammatory effect of cinnamaldehyde and linalool from the leaf essential oil of Cinnamomum osmophloeum Kanehira in endotoxin-induced mice. J. Food Drug Anal. 2018, 26, 211-220. [CrossRef]

41. Yu, C.-W.; Li, W.-H.; Hsu, F.-L.; Yen, P.-L.; Chang, S.-T.; Liao, V.H.-C. Essential Oil Alloaromadendrene from Mixed-Type Cinnamomum osmophloeum Leaves Prolongs the Lifespan in Caenorhabditis elegans. J. Agric. Food Chem. 2014, 62, 6159-6165. [CrossRef]

42. Chen, T.H.; Huang, Y.H.; Lin, J.J.; Liau, B.C.; Wang, S.Y.; Wu, Y.C.; Jong, T.T. Cytotoxic lignan esters from Cinnamomum osmophloeum. Planta Med. 2010, 76, 613-619. [CrossRef] [PubMed]

43. Lee, M.-J.; Rao, Y.K.; Chen, K.; Lee, Y.-C.; Tzeng, Y.-M. Effect of flavonol glycosides from cinnamomum osmophloeum leaves on adiponectin secretion and phosphorylation of insulin receptor- $\beta$ in 3t3-11 adipocytes. J. Ethnopharmacol. 2009, 126, 79-85. [CrossRef]

44. Cheng, B.-H.; Sheen, L.-Y.; Chang, S.-T. Evaluation of anxiolytic potency of essential oil and s-(+)-linalool from cinnamomum osmophloeum ct. Linalool leaves in mice. J. Tradit. Complement Med. 2014, 5, 27-34. [CrossRef] [PubMed]

45. Lin, S.-S.C.; Lu, T.-M.; Chao, P.-C.; Lai, Y.-Y.; Tsai, H.-T.; Chen, C.-S.; Lee, Y.-P.; Chen, S.-C.; Chou, M.-C.; Yang, C.-C. In Vivo Cytokine Modulatory Effects of Cinnamaldehyde, the Major Constituent of Leaf Essential Oil from Cinnamomum osmophloeum Kaneh. Phytother. Res. 2011, 25, 1511-1518. [CrossRef] [PubMed]

46. Theurer, M.; Shaik, N.; Lang, F. Stimulation of suicidal erythrocyte death by trans-cinnamaldehyde. Phytomedicine 2013, 20, 1119-1123. [CrossRef] [PubMed]

47. Mdoe, F.P.; Cheng, S.-S.; Msangi, S.; Nkwengulila, G.; Chang, S.-T.; Kweka, E.J. Activity of Cinnamomum osmophloeum leaf essential oil against Anopheles gambiae s.s. Parasit Vectors 2014, 7, 209. [CrossRef] [PubMed]

48. Cheng, S.-S.; Liu, J.-Y.; Tsai, K.-H.; Chen, W.-J.; Chang, S.-T. Chemical Composition and Mosquito Larvicidal Activity of Essential Oils from Leaves of Different Cinnamomum osmophloeum Provenances. J. Agric. Food Chem. 2004, 52, 4395-4400. [CrossRef]

49. Cheng, S.-S.; Liu, J.-Y.; Lin, C.-Y.; Hsui, Y.-R.; Lu, M.-C.; Wu, W.-J.; Chang, S.-T. Terminating red imported fire ants using Cinnamomum osmophloeum leaf essential oil. Bioresour. Technol. 2008, 99, 889-893. [CrossRef]

50. Cheng, S.-S.; Liu, J.-Y.; Huang, C.-G.; Hsui, Y.-R.; Chen, W.-J.; Chang, S.-T. Insecticidal activities of leaf essential oils from cinnamomum osmophloeum against three mosquito species. Bioresour. Technol. 2009, 100, 457-464. [CrossRef]

51. Shimizu, M.; Ito, T.; Terashima, S.; Hayashi, T.; Arisawa, M.; Morita, N.; Kurokawa, S.; Ito, K.; Hashimoto, Y. Inhibition of lens aldose reductase by flavonoids. Phytochemistry 1984, 23, 1885-1888. [CrossRef] 
52. Przygodzka, M.; Zielińska, D.; Ciesarová, Z.; Kukurová, K.; Zieliński, H. Comparison of methods for evaluation of the antioxidant capacity and phenolic compounds in common spices. LWT Food Sci. Technol. 2014, 58, 321-326. [CrossRef]

53. Guo, J.-Y.; Huo, H.-R.; Zhao, B.-S.; Liu, H.-B.; Li, L.-F.; Ma, Y.-Y.; Guo, S.-Y.; Jiang, T.-L. Cinnamaldehyde reduces IL-1 $\beta$-induced cyclooxygenase-2 activity in rat cerebral microvascular endothelial cells. Eur. J. Pharmacol. 2006, 537, 174-180. [CrossRef] [PubMed]

54. Gan, F.F.; Chua, Y.S.; Scarmagnani, S.; Palaniappan, P.; Franks, M.; Poobalasingam, T.; Bradshaw, T.D.; Westwell, A.D.; Hagen, T. Structure-activity analysis of $2^{\prime}$-modified cinnamaldehyde analogues as potential anticancer agents. Biochem. Biophys. Res. Commun. 2009, 387, 741-747. [CrossRef]

55. Wu, S.-J.; Ng, L.-T. MAPK inhibitors and pifithrin-alpha block cinnamaldehyde-induced apoptosis in human PLC/PRF/5 cells. Food Chem. Toxicol. 2007, 45, 2446-2453. [CrossRef]

56. Curra, M.; Soares Junior, L.A.V.; Martins, M.D.; Santos, P.S.d.S. Chemotherapy protocols and incidence of oral mucositis. An integrative review. Einstein (Sao Paulo) 2018, 16, eRW4007. [CrossRef] [PubMed]

57. Köstler, W.J.; Hejna, M.; Wenzel, C.; Zielinski, C.C. Oral Mucositis Complicating Chemotherapy and/or Radiotherapy: Options for Prevention and Treatment. CA: A Cancer J. Clin. 2001, 51, 290-315. [CrossRef]

58. Lalla, R.V.; Bowen, J.; Barasch, A.; Elting, L.; Epstein, J.; Keefe, D.M.; McGuire, D.B.; Migliorati, C.; Nicolatou-Galitis, O.; Peterson, D.E.; et al. MASCC/ISOO clinical practice guidelines for the management of mucositis secondary to cancer therapy. Cancer 2014, 120, 1453-1461. [CrossRef]

59. Molania, T.; Moghadamnia, A.A.; Pouramir, M.; Aghel, S.; Moslemi, D.; Ghassemi, L.; Motallebnejad, M. The effect of Cinnamaldehyde on mucositis and salivary antioxidant capacity in gamma-irradiated rats (a preliminary study). Daru 2012, 20, 89. [CrossRef]

60. Parkins, C.S.; Fowler, J.F.; Yu, S. A murine model of lip epidermal/mucosal reactions to X-irradiation. Radiother. Oncol. 1983, 1, 159-165. [CrossRef]

61. Veilleux, M.-P.; Grenier, D. Determination of the effects of cinnamon bark fractions on Candida albicans and oral epithelial cells. BMC Complement. Altern. Med. 2019, 19, 303. [CrossRef]

62. Feghali, K.; Feldman, M.; La, V.D.; Santos, J.; Grenier, D. Cranberry Proanthocyanidins: Natural Weapons against Periodontal Diseases. J. Agric. Food Chem. 2012, 60, 5728-5735. [CrossRef] [PubMed]

63. Raeessi, M.A.; Raeessi, N.; Panahi, Y.; Gharaie, H.; Davoudi, S.M.; Saadat, A.; Karimi Zarchi, A.A.; Raeessi, F.; Ahmadi, S.M.; Jalalian, H. "Coffee plus honey" versus "topical steroid" in the treatment of chemotherapy-induced oral mucositis: A randomised controlled trial. BMC Complement. Altern. Med. 2014, 14, 293. [CrossRef] [PubMed]

64. Fidler, P.; Loprinzi, C.L.; O’Fallon, J.R.; Leitch, J.M.; Lee, J.K.; Hayes, D.L.; Novotny, P.; Clemens-Schutjer, D.; Bartel, J.; Michalak, J.C. Prospective evaluation of a chamomile mouthwash for prevention of 5-FU-induced oral mucositis. Cancer 1996, 77, 522-525. [CrossRef]

65. Mazokopakis, E.E.; Vrentzos, G.E.; Papadakis, J.A.; Babalis, D.E.; Ganotakis, E.S. Wild chamomile (Matricaria recutita L.) mouthwashes in methotrexate-induced oral mucositis. Phytomedicine 2005, 12, 25-27. [CrossRef]

66. Pourdeghatkar, F.; Motaghi, M.; Darbandi, B.; BagherSalimi, A. The Effect of Chamomile Mouthwash on the Prevention of Oral Mucositis Caused by Chemotherapy in Children with Acute Lymphoblastic Leukemia. SSU 2017, 7, 76-81.

67. Aoyama, T.; Nishikawa, K.; Takiguchi, N.; Tanabe, K.; Imano, M.; Fukushima, R.; Sakamoto, J.; Oba, M.S.; Morita, S.; Kono, T.; et al. Double-blind, placebo-controlled, randomized phase II study of TJ-14 (hangeshashinto) for gastric cancer chemotherapy-induced oral mucositis. Cancer Chemother Pharm. 2014, 73, 1047-1054. [CrossRef]

68. Kono, T.; Kaneko, A.; Matsumoto, C.; Miyagi, C.; Ohbuchi, K.; Mizuhara, Y.; Miyano, K.; Uezono, Y. Multitargeted Effects of Hangeshashinto for Treatment of Chemotherapy-Induced Oral Mucositis on Inducible Prostaglandin E2 Production in Human Oral Keratinocytes. Integr. Cancer Ther. 2014, 13, 435-445. [CrossRef]

69. You, W.C.; Hsieh, C.C.; Huang, J.T. Effect of Extracts from Indigowood Root (Isatis indigotica Fort.) on Immune Responses in Radiation-Induced Mucositis. J. Altern. Complementary Med. 2009, 15, 771-778. [CrossRef]

70. Tiemann, P.; Toelg, M.; Ramos, F.M.H. Administration of Ratanhia-based herbal oral care products for the prophylaxis of oral mucositis in cancer chemotherapy patients: A clinical trial. Evid Based Complement. Altern. Med. 2007, 4, 361-366. [CrossRef] 
71. Sahebjamee, M.; Mansourian, A.; Hajimirzamohammad, M.; Zadeh, M.T.; Bekhradi, R.; Kazemian, A.; Manifar, S.; Ashnagar, S.; Doroudgar, K. Comparative Efficacy of Aloe vera and Benzydamine Mouthwashes on Radiation-induced Oral Mucositis: A Triple-blind, Randomised, Controlled Clinical Trial. Oral Health Prev. Dent. 2015, 13, 309-315. [CrossRef]

72. Hawley, P.; Hovan, A.; McGahan, C.E.; Saunders, D. A randomized placebo-controlled trial of manuka honey for radiation-induced oral mucositis. Supportive Care Cancer 2014, 22, 751-761. [CrossRef]

73. Miranzadeh, S.; Adib-Hajbaghery, M.; Soleymanpoor, L.; Ehsani, M. A New mouthwash for Chemotherapy Induced Stomatitis. Nurs. Midwifery Stud. 2014, 3, e20249. [CrossRef] [PubMed]

74. Babaee, N.; Moslemi, D.; Khalilpour, M.; Vejdani, F.; Moghadamnia, Y.; Bijani, A.; Baradaran, M.; Kazemi, M.T.; Khalilpour, A.; Pouramir, M.; et al. Antioxidant capacity of calendula officinalis flowers extract and prevention of radiation induced oropharyngeal mucositis in patients with head and neck cancers: A randomized controlled clinical study. Daru 2013, 21, 18. [CrossRef] [PubMed]

75. Khanal, B.; Baliga, M.; Uppal, N. Effect of topical honey on limitation of radiation-induced oral mucositis: An intervention study. Int. J. Oral Maxillofac. Surg. 2010, 39, 1181-1185. [CrossRef] [PubMed]

76. Kuduban, O.; Mazlumoglu, M.R.; Kuduban, S.D.; Erhan, E.; Cetin, N.; Kukula, O.; Yarali, O.; Cimen, F.K.; Cankaya, M. The effect of hippophae rhamnoides extract on oral mucositis induced in rats with methotrexate. J. Appl Oral Sci 2016, 24, 423-430. [CrossRef]

77. Motallebnejad, M.; Akram, S.; Moghadamnia, A.; Moulana, Z.; Omidi, S. The effect of topical application of pure honey on radiation-induced mucositis: A randomized clinical trial. J. Contemp. Dent. Pract. 2008, 9, 40-47. [CrossRef]

78. Rashad, U.M.; Al-Gezawy, S.M.; El-Gezawy, E.; Azzaz, A.N. Honey as topical prophylaxis against radiochemotherapy-induced mucositis in head and neck cancer. J. Laryngol. Otol. 2009, 123, $223-228$. [CrossRef]

79. Lambros, M.P.; Kondapalli, L.; Parsa, C.; Mulamalla, H.C.; Orlando, R.; Pon, D.; Huang, Y.; Chow, M.S.S. Molecular signatures in the prevention of radiation damage by the synergistic effect of n-acetyl cysteine and qingre liyan decoction, a traditional chinese medicine, using a 3-dimensional cell culture model of oral mucositis. Evid. Based Complement Alternat. Med. 2015, 2015, 425760. [CrossRef]

80. Loo, W.T.Y.; Jin, L.J.; Chow, L.W.C.; Cheung, M.N.B.; Wang, M. Rhodiola algida improves chemotherapy-induced oral mucositis in breast cancer patients. Expert Opin. Investig. Drugs 2010, 19, S91-S100. [CrossRef]

81. Wu, M.-h.; Yuan, B.; Liu, Q.-f.; Wang, Q. Study of qingre liyan decoction (清热利咽汤) in treating and preventing acute radioactive oral mucositis. Chin. J. Integr. Med. 2007, 13, 280-284. [CrossRef]

82. Puataweepong, P.; Dhanachai, M.; Dangprasert, S.; Sithatani, C.; Sawangsilp, T.; Narkwong, L.; Puttikaran, P.; Intragumtornchai, $\mathrm{T}$. The efficacy of oral aloe vera juice for radiation induced mucositis in head and neck cancer patients: A double-blind placebo-controlled study. Asian Biomedicine 2009, 3, 375-382.

83. De Freitas Cuba, L.; Braga Filho, A.; Cherubini, K.; Salum, F.G.; Figueiredo, M.A.Z.d. Topical application of aloe vera and vitamin e on induced ulcers on the tongue of rats subjected to radiation: Clinical and histological evaluation. Support. Care Cancer 2016, 24, 2557-2564. [CrossRef] [PubMed]

84. Sencer, S.F.; Zhou, T.; Freedman, L.S.; Ives, J.A.; Chen, Z.; Wall, D.; Nieder, M.L.; Grupp, S.A.; Yu, L.C.; Sahdev, I.; et al. Traumeel s in preventing and treating mucositis in young patients undergoing sct: A report of the children's oncology group. Bone Marrow Transplant 2012, 47, 1409-1414. [CrossRef] [PubMed]

85. Braga, F.T.M.M.; Santos, A.C.F.; Bueno, P.C.P.; Silveira, R.C.C.P.; Santos, C.B.; Bastos, J.K.; Carvalho, E.C. Use of chamomilla recutita in the prevention and treatment of oral mucositis in patients undergoing hematopoietic stem cell transplantation: A randomized, controlled, phase ii clinical trial. Cancer Nursing 2015, 38, 322-329. [CrossRef]

86. Napeñas, J.J.; Brennan, M.T.; Coleman, S.; Kent, M.L.; Noll, J.; Frenette, G.; Nussbaum, M.L.; Mougeot, J.-L.; Paster, B.J.; Lockhart, P.B.; et al. Molecular methodology to assess the impact of cancer chemotherapy on the oral bacterial flora: A pilot study. Oral Surg. Oral Med. Oral Pathol. Oral Radiol. Endodontol. 2010, 109, 554-560. [CrossRef]

87. Sonalika, W.G.; Amsavardani Tayaar, S.; Bhat, K.G.; Patil, B.R.; Muddapur, M.V. Oral microbial carriage in oral squamous cell carcinoma patients at the time of diagnosis and during radiotherapy - A comparative study. Oral Oncol. 2012, 48, 881-886. [CrossRef] 
88. Panghal, M.; Kaushal, V.; Kadayan, S.; Yadav, J.P. Incidence and risk factors for infection in oral cancer patients undergoing different treatments protocols. BMC Oral Health 2012, 12, 22. [CrossRef]

89. Laheij, A.M.G.A.; de Soet, J.J.; von dem Borne, P.A.; Kuijper, E.J.; Kraneveld, E.A.; van Loveren, C.; Raber-Durlacher, J.E. Oral bacteria and yeasts in relationship to oral ulcerations in hematopoietic stem cell transplant recipients. Supportive Care Cancer 2012, 20, 3231-3240. [CrossRef]

90. Cechinel-Zanchett, C.C.; Boeing, T.; Somensi, L.B.; Steimbach, V.M.B.; Campos, A.; Krueger, C.d.M.A.; Schultz, C.; Sant'ana, D.d.M.G.; Cechinel-Filho, V.; Mota da Silva, L.; et al. Flavonoid-rich fraction of Bauhinia forficata Link leaves prevents the intestinal toxic effects of irinotecan chemotherapy in IEC- 6 cells and in mice. Phytother. Res. 2019, 33, 90-106. [CrossRef]

91. Liu, Z.; Xi, J.; Schröder, S.; Wang, W.; Xie, T.; Wang, Z.; Bao, S.; Fei, J. Chimonanthus nitens var. salicifolius Aqueous Extract Protects against 5-Fluorouracil Induced Gastrointestinal Mucositis in a Mouse Model. Evid. -Based Complementary Altern. Med. 2013, 2013, 12. [CrossRef]

92. Vladimir, R.A.S.N.; Gustavo, S.A.; Rafael, T.G.; Samara, H.I.; Maralice, C.B.; Evandro, N.A.; Efigenia Ferreira e, F.; Ana Cristina Viana, C.; Alexandre, A.S.; Sheila, R.L.A.; et al. Mucoadhesive Propolis Gel for Prevention of Radiation-Induced Oral Mucositis. Curr. Clin. Pharmacol. 2014, 9, 359-364. [CrossRef]

93. Georgakopoulou, E.A. Cinnamon contact stomatitis. J. Derm. Case Rep. 2010, 4, 28-29. [CrossRef] [PubMed]

94. Tremblay, S.; Avon, S.L. Contact allergy to cinnamon: Case report. J. Can. Dent. Assoc. 2008, 74, $445-461$. [PubMed]

95. Calapai, G.; Miroddi, M.; Mannucci, C.; Minciullo, P.L.; Gangemi, S. Oral adverse reactions due to cinnamon-flavoured chewing gums consumption. Oral Dis. 2014, 20, 637-643. [CrossRef]

(C) 2020 by the authors. Licensee MDPI, Basel, Switzerland. This article is an open access article distributed under the terms and conditions of the Creative Commons Attribution (CC BY) license (http://creativecommons.org/licenses/by/4.0/). 